\title{
The Flag Insulted: U.S. Merchant Marine Incidents, 1865-1895
}

\section{Rodney Carlisle}

Les intérêts américains, autant de la marine marchande que d'autres entreprises engagées dans le commerce extérieur, ont exigé de fortes réponses gouvernementales au mal-traitement par d'autres puissances des vaisseaux battant pavillon des États-Unis dans la dernière partie du 19ème siècle. L'article actuel argue du fait que ces demandes ont réussi. Dans certains cas le gouvernement des États-Unis a entrepris des représailles de force, et dans les années 1880 le gouvernement a commencé à renforcer sa marine de guerre. Les dirigeants américains ont été influencés par une crainte parmi l'électorat qui le déclin abrupte, depuis la fin de la guerre civile, de la marine marchande, jadis de grande importance, et de la marine de guerre des États-Unis aurait eu comme conséquence que les États-Unis puissent être considérés avec mépris par d'autres nations. De ces craintes a émergé un " culte du drapeau. " Cette insistance que le drapeau soit respecté et défendu là où il naviguait a alimenté un nationalisme et un expansionnisme américains qui ont mené vers la déclaration de la guerre avec l'Espagne en 1898. Le "culte du drapeau » a également contribué à l'entrée américaine dans la première guerre mondiale, comme réponse directe aux attaques des sous-marins allemands sur les navires marchands battant pavillon américain.

In the three decades following the Civil War, U.S. ship owners and other entrepreneurs extended the reach and influence of the United States abroad. By expecting and then demanding the protection of the American flag in their overseas business operations, and by viewing their activities as redounding to the power and influence of the United States, they laid the foundations for the emergence of the United States as a major world power. In effect, the flag followed the dollar. As that process unfolded, U.S. public opinion became enlisted in support by instances in which foreign powers did not show respect for the U.S. flag.

"Affronts to the flag," in Korea, Formosa, and in the Caribbean and the Bering seas led to demands for the use of force to extract retribution or apology. Increasingly through the period, journalists and politicians sought to evoke popular indignation by portraying international incidents involving merchant ships as insults to the flag. Presidents and secretaries of state, pressured and then empowered by public opinion,

The Northern Mariner/le marin du nord, XX No. 3, (July 2010), 267-282 
sometimes employed ironclads, gunboats, and the new steel navy to seek respect for the flag through the display of force. From a modern perspective, the language employed by journalists and politicians regarding minor maritime incidents is redolent with an exaggerated focus on the flag.

Modern sociologists and group psychologists have identified this phenomenon as the rise of "the cult of the flag," in which the flag itself serves as a "totem" to be revered, honored, treated ceremoniously, and avenged with blood sacrifice when affronted. Sociologists draw such conclusions by comparing the practices of modern societies with those of pre-industrial societies, like those found among Native Americans, Polynesians, Australian aborigines and isolated groups in Africa. The episodes discussed here support the idea that such a cult took root in the United States in the post Civil War era. ${ }^{1}$

Historians have looked at the phenomenon of exaggerated reverence for the flag simply as symptoms of an increasingly emotional nationalism or "jingoism." The tone of offended nationality, and the chip-on-the-shoulder attitude have been treated as precursors to the brief war with Spain in 1898, and to the series of engagements abroad in the first decades of the twentieth century under Theodore Roosevelt, William Howard Taft, and Woodrow Wilson. Some have seen the overseas imperialism of the United States in those decades as carrying the "frontier" abroad, in a kind of "blue water expansionism" from the mid 1890s to the 1920s. Viewed through such an extension of Frederick Jackson Turner's frontier thesis, the fishermen, sealers, overseas planters, and China traders were much like the frontiersmen of earlier decades, pushing U.S. interests into a lawless part of the world. ${ }^{2}$

A close examination of the maritime encounters of 1865-1895 suggests the degree to which the episodes evoked deep emotional responses, often far out of proportion to the severity of the events. A few of the encounters were violent, resulting in the death of U.S. seamen and the destruction or impounding of their ships; in other cases, U.S. ships were hailed with a warning shot, stopped, and detained. In still other incidents, U.S. ships were commandeered by armed forces for use in a local conflict. Each episode was different in its causes and consequences, but, increasingly through the decades, officials and journalists regarded such events not simply as matters of maritime legality or the vicissitudes of trading in waters troubled by war or revolution, but as "insults to the flag."

The dozens of incidents involving the U.S. merchant flag through these years have received scant treatment in the major historical studies of U.S. foreign policy through the period. Yet the episodes raise a number of important questions. Did the

1 A thorough exploration of this thesis can be found in Carolyn Marvin and David Ingle, Blood Sacrifice and the Nation: Totem Rituals and the American Flag (New York: Cambridge University Press, 1999).

2 An extensive literature regarding blue-water imperialism has been developed by American historians, including Ernest May, Philip Foner, Victor Perlo, and many others. Walter Lefeber, in The New Empire: An Interpretation of American Expansion, 1860-1898 (Ithaca, NY: Cornell University Press, 1998) traces the rise of U. S. overseas imperialism in the period under discussion in this article. 
treatment of U.S. merchant ships, fishing boats, and whalers in the period represent an actual or only a perceived international disdain for the claim of the United States of America to being a major world power? Were the incidents exploited and blown out of proportion by American commercial interests and navalist advocates in attempts to win political support? How did particular diplomats and secretaries of state deal with the issues that arose in regard to the episodes? Was the sensitivity to "affronts" justified in any objective sense, or was it only symptomatic of the undercurrent of jingoism in the era, or as sociologists would say, the emergence of the "cult of the flag" and the conversion of the flag into a totem? In this brief article, such questions can only be suggested, and sources for future research indicated.

Considering the small scale of some sixty or more incidents, ${ }^{3}$ and considering the ambiguous legal standing of many of the ships, the contemporary concern of diplomats, journalists and politicians is itself revelatory. Episodes involving just a few seamen and officers, often engaged in activities that others would see as smuggling, violation of portstate piloting or fishing grounds regulation, support of criminal or insurgent forces, or outright filibustering, often received very generous treatment in the forum of U.S. public opinion. The reasons for the defense, and, sometimes, the outright glorification of some of the seamen who were in fact scoundrels with dubious backgrounds, reveal some aspects of the U.S. self-image of the era. That self-image, when it came to maritime affairs, seemed characterized by an awareness of inadequacy, the sort of bluster associated with insecure schoolyard bullies. A review of the state of U.S. shipping hints at legitimate causes for this apparent sense of maritime inferiority.

In the post-Civil War decades, U.S. statesmen and the broader public were familiar with the maritime heritage and history of the United States. Heroes such as John Paul Jones, Oliver Hazard Perry, and David Farragut were remembered by every school boy. The glory days of U.S. clipper ships and a rising sail-powered merchant marine were also well-remembered. As the period receded into the past, it already acquired a mystique and romance, fueled by and reflected in the literary works of Herman Melville and Richard Henry Dana, in the works of lesser known writers, and in thousands of pieces of nautical art. ${ }^{4}$ For a generation of citizens developing a nationalistic self-identity, in which a mythologized history played a central part, the decline of U.S. shipping following the Civil War was a source of dismay.

The reasons for the decline were much debated. It was clear that hundreds of the best U.S. ships had left U.S. registry during the Civil War, to escape the depredations of the handful of Confederate raiding cruisers. After the war, there was no recovery of the

3 More than sixty episodes rose to the level of concern such that they were reported either in diplomatic correspondence collected in Foreign Relations of the United States (henceforth, FRUS), or were reported in the New York Times (henceforth NYT) or in both sources in the period 1865-1895. Although there may have been as many more minor encounters in the period, the diplomatic and newspaper accounts of the episodes listed here are the most accessible.

4 Coverage of the nautical art in the period is captured in J. Welles Henderson, Jack Tar: A Sailor's Life, 1750-1910 (Woodbridge, UK: Antique Collector's Press, 1999). 
U.S. merchant fleet for a number of reasons. Ship builders, hoping for increased business, backed a Congressional prohibition on the re-registry under the U.S. flag of ships that had transferred to Britain, in effect blocking a post-war resurgence of American shipping. As British shipyards built steam-propelled iron freighters, shipyards in the United States could not compete in the cost of materials or labor. The long-distance trades of the United States made sail power seem more reliable than steam power that relied on ready supplies of coal, tending to retard U.S. technical progress in shipbuilding.

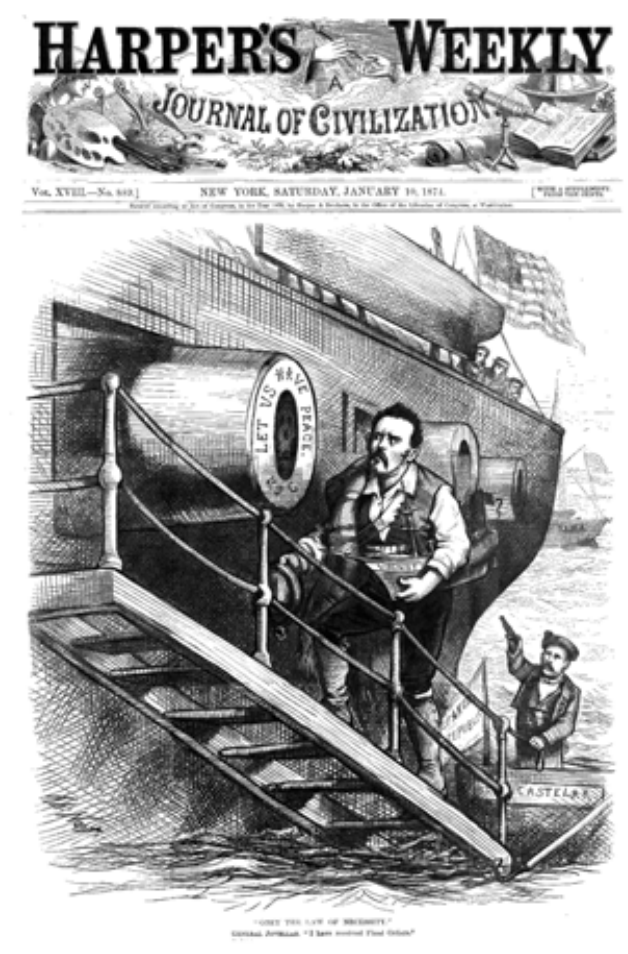

Illustration 1: "Let us have peace" - cover of Harper's Weekly, 10 January 1874.

While Congress considered remedies to the problem, ship owners and shipbuilders had differing and sometimes conflicting financial interests, while much of the voting public in the interior of the nation had little sympathy for spending federal funds on businesses located in a few coastal cities. As a consequence of a continuing deadlock between conflicting maritime interests, there was no successful federal aid to the maritime industries until a postal subsidy was passed in 1891, and that aid had only minor results. Meanwhile, despite the efforts of several secretaries of the navy to maintain and rebuild the U.S. Navy, Congress provided no funding for new naval shipbuilding in the period 1865 to 1881 , leading to the rapid obsolescence of the Navy's fleet of warships. The first four ships of the new steel Navy built beginning in 1884, although a herald of the stronger Navy that would follow in later years, represented a small and troublewracked little "White Squadron," hardly worthy of the name "New Navy" so often attached to it in the press and in history.

During the post Civil War period, several political/historical treatises focused on the failure of the United States to live up to its proud maritime heritage: David A. Wells, Our Merchant Marine: How It Rose, Increased, Became Great, Declined, and Decayed (1882); William A. Bates, American Marine: The Shipping Question in History and Politics (1892) and Bates, American Navigation: The Political History of Its Rise and Ruin (1902). These statistical works, reliant on governmental reports, were intended to stir support for reform measures. Others appeared in the same vein: Henry Hall, American Navigation, With Some Account of the Causes of Its Former Prosperity and Present Decline (1878), and Charles S. Hill, History of American Shipping: Its Prestige, Decline, and Prospect (1883). These five works, published between 1878 and 1902 (four of them between 1878 and 1892), all reflected the concern with the contrast between the former greatness of the U. S. 
merchant marine and its "decline," in the era following the Civil War. There were numerous periodical articles in the period with similar themes. ${ }^{5}$

The focus of these works was almost entirely on the economic side of the issue, that is, the decline of U.S. ship-owning, ship-building, and U.S. shipping lines in the face of British competition and the rise of steam. Publicists debated both sides of the issues of whether there should be subsidies for ship owners in the form of postal contracts and whether protective tariffs on materials used in shipbuilding should be lowered or eliminated. There was little or no discussion in these books and articles of a perceived failure of the State Department or Navy Department to come to the aid of distressed U.S. ships abroad. Nevertheless, the rich literature on the "decline of American shipping" reflected the notion that shipping was part of a nation's prestige and greatness. In effect, these works all reflected the commercial side of the Mahan argument regarding sea power, and all expressed concern that the U.S. merchant fleet had become inadequate to match the nation's position in the world. Alfred Thayer Mahan published his thoughtprovoking Influence of Sea Power on History, 1660-1783, in 1890, marrying the naval and maritime concerns prevalent in the period.

With a declining merchant marine, a small and ineffective navy, but with a maritime heritage of vigorous defense of the American flag abroad, the sensitivity of policy makers and maritime advocates to "insults," "affronts," and "outrages," even in minor encounters, seems somewhat understandable. Just as the nation was experiencing a domestic triumphalism with the opening of the West, the completion of the transcontinental railroad, and a booming expansion of industry, agriculture, and immigration, America's flag overseas seemed to be almost constantly running into indignities, and its protection abroad seemed shamefully inadequate.

In retrospect, it is easy to see the blustering concern with insults and affronts as an expression of a national maritime inferiority complex. However, viewed in another light, the incidents may in fact have demonstrated the weakness of the United States in the period. The U.S. Navy was in reality rather powerless to protect U.S. ships in these incidents. The few times that U.S. naval forces engaged in punitive expeditions to exact retribution for offenses against American commercial ships contrasted rather strongly with the repeated and aggressive assertion of power by the navies of Great Britain, France, Germany, Japan, Italy, and Chile during the same years.

It should be noted that the American sense of "outrage" over supposed affronts to

5 A partial selection of such treatises and articles: John Roach, Decline of American Shipping: Reasons and Remedy (December 1882); C.J. Brockway, "A defense of American Shipping," International Review (January 1883); Joseph Hutchinson, American Shipping (May 1883); Nelson Dingley, "The Decline of American Shipping," North American Review (April 1884); E.P. North, "American Shipping, the Disease and the Remedy," North American Review (May 1888); John Hall, "The Decline of our Merchant marine," Overland Monthly and Out West Magazine (December 1888); Percy Thompson, "Our Merchant marine-The Causes of its Depression," Belford's Monthly and Democratic Review (March 1892)." Numerous unsigned editorials through the period reiterated the same issue, for example: "The Merchant Marine," NYT, 27 June 1868, and “Our Shipping Interests," NYT, 2 September 1872. 
the flag was not unique. Germany, Britain, Spain, and the newly emerging sea-power states of Latin America (Chile in particular), all displayed a similar degree of sensitivity to the treatment of their maritime flag abroad in this period. Given the rule in international law that a ship was part of the sovereignty of the state whose flag she flew, the governments and publics of all of these maritime states expected their maritime flag to be properly respected abroad.

Although U.S. presidents and secretaries of state dabbled with "gunboat diplomacy" through the three decades, they had very little in the way of naval force with which to work. As a consequence, rulers of extremely weak nations, such as Korea and Formosa, and even those wracked by constant internal conflict such as Haiti, the Dominican Republic, and Colombia had little compunction in detaining U.S. vessels when it suited their purposes, or even confiscating them temporarily or permanently to use in local military conflicts. Despite the outcries of rage from certain politicians and particular newspapers, most, but not all, of the affronts went un-avenged.

An 1866 episode resulted in a long-delayed retaliation in 1871. The misadventures of the officers and crew of the trading ship General Sherman in 1866 at first drew little attention for several reasons. The incident happened in Korea, or "Corea," as it was known at the time, a remote, semi-independent kingdom under the nominal control of China. Like Japan, Korea had remained isolated from foreign influences by choice, and sources of information about the "Hermit kingdom" were very sparse. Details of the episode were sketchy at first, since all of the crew had been slaughtered. In addition, it was not clear to United States officials what actions on the part of the ship's crew had led to the incident. Whether or not the crew had violated Korean laws and customs, how they met their demise, and whether British and French, as well as U.S. interests were at stake, all remained unclear for several years. Some reports indicated the U.S. ship had been engaged in a hare-brained scheme to raid the Korean capital, and "kidnap" the preserved and revered body of a former ruler.

In 1866-1867, the U.S. press and public were deeply engaged in controversies over the administration of Andrew Johnson, Lincoln's successor, and over the nature of Reconstruction in the South. The death of a few adventurers in such a remote and unknown region, where they had apparently proceeded up river in violation of local law, could hardly compete for public attention with struggles over possible presidential impeachment and the attempts of Southern legislators to restore the power and position of the planter aristocracy in the South.

Nevertheless, the episode of the General Sherman merited investigation, and after several years, the Navy launched a punitive expedition against Korea in 1871. Emulating the earlier "opening of Japan" by Matthew Perry, U.S. naval officer Robert W. Shufeldt eventually obtained a treaty opening the Hermit Kingdom to U.S. trade, in $1882 .{ }^{6}$

During the American Civil War, the United States was in no position to assert the

6 Boleslaw Szczesniak, "Letters of Homer Crane Blake Concerning his Naval Expedition to China, Japan, and Korea, 1869-1872," Monumenta Nipponica (October 1957), 313-328; Frederick C. Drake, Empire of the Seas: A Biography of Robert Wilson Shufeldt, USN (Honolulu: University of Hawaii Press, 1984). 
so-called Monroe Doctrine, prohibiting the extension of European controlled territory or new colonies in the Western Hemisphere. Partly as a consequence of the preoccupation of the United States with its internal crisis, the Spanish engaged in a naval war with Chile and Peru over claims to off-shore islands, re-established control over the eastern half of Hispaniola (now the Dominican Republic), and tightened its authoritarian rule over Cuba and Puerto Rico. Meanwhile, France, through the establishment of Archduke Maximilian on the Imperial throne of Mexico, turned that independent republic temporarily into a form of French protectorate on the border of the United States. The State Department received complaints regarding the treatment of U.S. ships by France, and more especially by Spain, through 1866 and 1867. Despite the aspirations of Secretary of State William Seward to extend U.S. hegemony in the Caribbean and North America, he was in no position to do more than investigate such issues and to present objections to the imperial powers.

In the three years following the Civil War, incidents arising in Latin America and in the Pacific over the ships shown in Table 1 rose to the level of diplomatic concern. Records regarding the episodes shown in this and later tables can be found in Foreign Relations of the United States (FRUS) and in the New York Times (NYT). The press took note that minor powers, such as Honduras, Ecuador, and the kingdom of Hawaii showed little compunction in interfering with American-flagged merchant ships.

\begin{tabular}{|l|l|l|}
\hline \multicolumn{3}{|l|}{ TABLE 1 - U.S. Ship Incidents, $\mathbf{1 8 6 5}-\mathbf{1 8 6 7}$} \\
\hline Year & Ships & Incident \\
\hline 1865 & Apure & Venezuela \\
\hline 1865 & Antioquia & Colombia, ship detained \\
\hline 1865 & Washington & Ecuador; ship turned over to rebels \\
\hline 1866 & General Sherman & Korea; crew slaughtered \\
\hline 1866 & Josephine, Blue Jacket & Hawaii; local court dismissed seamen \\
\hline 1866 & Odessa & Peru; confiscated by US ship \\
\hline 1866 & William L. Richardson & Mexico; French seizure for blasting powder \\
\hline 1866 & Muhlenberg (sloop) & Honduras; abandoned surety for lawsuit \\
\hline 1866 & I.F.Chapman & Spain; quarantine unfairly imposed \\
\hline 1867 & Canandagua & Spain; quarantine unfairly imposed \\
\hline 1867 & Young Turk & Spain; quarantine unfairly imposed \\
\hline 1867 & R.R.Cuyler & Spain; neutrality violation alleged \\
\hline 1867 & Oneoto,Catawba & Spain; neutrality violation alleged \\
\hline 1867 & Rover & Formosa, crew slaughtered \\
\hline
\end{tabular}

Sources for table: FRUS, 1865-1869; selected issues NYT: Cuyler: 15 February 1867; Rover: 14, 15, 24, August 1867. 
In 1867, shipwrecked survivors from the U.S. ship Rover were murdered on the island of Formosa (now Taiwan). Like Korea, Formosa was under the loose imperial administration of China, and the inhabitants of the island treated all foreigners, especially Westerners, with suspicion and hostility. In this case, the U.S. Navy responded rather rapidly. The details of the incident and the language employed by State Department officials, by naval officers, and by the press, reflected not only the racial chauvinism of the era, but also, the emerging set of values that would coalesce into a belligerent form of nationalism. The Formosans who had attacked the sailors from the Rover were characterized as "savages," and the U.S. Navy conducted a retaliatory expedition in August 1867 to avenge the crime. ${ }^{7}$

In 1869, U.S. Grant took office as president, replacing Andrew Johnson. After some floundering in the choice of cabinet members, Grant settled on Hamilton Fish as secretary of state, and George Robeson as secretary of the Navy. Fish, unlike some of Grant's other appointees, was a competent statesman, and his administration of foreign affairs was regarded then and by historians as a bright spot in an often corrupt and incompetent administration. As episodes involving U.S. ships plying the nearby waters of the Caribbean and West Indies came to his attention, Fish worked to resolve the difficulties and to avoid international conflict. Nevertheless, his handling of several episodes through the period indicated some bedrock principles about the protection of U.S. interests abroad, and regarding affronts to flag in foreign waters. ${ }^{8}$

There were at least five cases of misuse or other affronts to the U.S. maritime flag in the period, 1868-1871 shown in Table 2.

\begin{tabular}{|l|l|l|}
\hline \multicolumn{3}{|l|}{ TABLE 2 - U.S. Ship Incidents, $\mathbf{1 8 6 8 - 1 8 7 1}$} \\
\hline Year & Ships & Incident \\
\hline 1868 & Liberte/Maratanza & Haiti; false flag \\
\hline 1869 & Tybee/Telegrafo & Santo Domingo; pretext for aid to government \\
\hline 1871 & Montijo & Colombia, commandeered \\
\hline 1871 & Florida & Cuba \\
\hline 1871 & Hornet & Cuba-Haiti; ship appropriated \\
\hline
\end{tabular}

Sources: Tybee/Telegrafo: Charles Tansill. The United States and Santo Domingo, 1778-1873: A Chapter in Caribbean Diplomacy(Baltimore: Johns Hopkins University Press, 1938), 369; NYT, 2 July, 1869; Report of the Select Committee of the Senate on the Memorial of Davis Hatch, Senate Report No. 234, 41 ${ }^{\text {st }}$ Congress, $2^{\text {nd }}$ session (Washington, 1870). Montijo: E. Taylor Parks. Colombia and the United States, 1765-1934 (Durham, NC: Duke University Press, 1935), 307308; Florida: NYT, 13 January 1872; Hornet: NYT, 21 October 1871; FRUS, 1868-1872.

7 The retaliatory expedition in response to the original incident is reported in "The Pirates of Formosa; Official Reports of the Engagement of United States Naval Forces with the Savages of the Island," NYT, 24 August 1867.

8 Spanish-US arbitration discussed by Hamilton Fish, FRUS, 1871-71, $744 \mathrm{ff}$. 
By far the most serious and well-known ship episode of the era occurred in 1873, with the capture of the ship Virginius by Spanish authorities off Cuba, and the execution by firing squad of many of the crew and passengers. The ship had been outfitted in New York, and sailed with an American flag aboard, carrying volunteers and munitions to aid Cuban rebels against Spanish rule. Secretary of State Hamilton Fish handled the crisis with aplomb, and although elements of the press and public clamored for a more warlike response, the case came to a peaceful resolution. ${ }^{9}$

Through the two Grant administrations that lasted from March 1869 until March 1877, U.S. merchant ships continued to run afoul of local authorities as they traded through the Caribbean and into the South Pacific. A typical news story, describing the events surrounding the Tybee incident reflects the language used, calling it "another outrage upon the American flag." 10

An odd assortment of legitimate traders, gun-runners (who preferred to be regarded as arms exporters), adventurers, whalers, and others believed they had cause to complain of the lack of respect shown the American flag aboard their ships. Incidents involving U.S. ships continued around the world as shown in Table 3.

\begin{tabular}{|l|l|l|}
\hline \multicolumn{4}{|l|}{ TABLE 3 - S. Ship Incidents, 1872-1876 } \\
\hline Year & Ships & Incident \\
\hline 1872 & James Bliss & Canada; insult flag \\
\hline 1873 & Virginius & Cuba; misuse flag; crew executed \\
\hline 1873 & Generalisimo Conquistador (ex Sherman) & Guatemala; misuse flag \\
\hline 1876 & Tybee & Santo Domingo \\
\hline
\end{tabular}

Sources: FRUS, 1872-1873; Virginius: NYT, numerous issues, 1873; Generalisimo Conquistador (ex Sherman): Frank Leslie's Magazine (June 1880); Tybee: NYT, 8 July 1876.

During the administrations of Rutherford Hayes (1877-1881) and James Garfield (1881), Secretary of State William Evarts and his volatile successor, James G. Blaine confronted a highly risky situation that could easily have involved the nation in a war with Chile. The fact that the Chilean navy was far more powerful, well-equipped, and apparently had better morale and training than the U.S. Navy made such a prospect daunting. Chile fought a three-year war with neighboring Peru and Bolivia, effectively defeating both, gaining control over disputed provinces of Tacna and Arica, rich in nitrate

9 The incident was widely reported in the press. NYT: 8 November, 10 November, 15 November, 21 November 1873, and 6 January 1874; Henry Ward Beecher, "Cuba and the Brotherhood of Nations," Christian Union, 26 November 1873; "The Case of the Virginius," Christian Union, 19 November 1873; "The Difficulty with Spain," New York Evangelist, 11 December 1873. These are only a few of the many news items regarding Virginius published at the time. The best modern secondary source on this episode is Richard Bradford, The Virginius Affair (Boulder: Colorado Assoc. Universities Press, 1980).

10 "The American Flag, How it is regarded by the Government of Santo Domingo," NYT, 8 July 1876. 
deposits. This War of the Pacific engaged no direct interests of the United States, and official policy was one of strict neutrality. Neutrality, by U.S. standards, meant that U.S. traders had the right to continue trade with both sides, subject to interdiction by any effective blockade. As the war continued, the danger that U.S. neutrality might lead to conflict (as it had with Britain in 1812) remained imminent. Several ship episodes tested the limits and boundaries of the policy. Blaine's stumbling efforts to intervene, and the missteps of U.S. ministers to both Peru and Chile also contributed to a set of foreign policy debacles. ${ }^{11}$

\begin{tabular}{|l|l|l|}
\hline \multicolumn{3}{|l|}{ TABLE 4 - U.S. Ship Incidents, 1877-1881 } \\
\hline Year & Ships & Incident \\
\hline 1877 & Rising Sun & Whaler; detained off Cuba; “outrage" \\
\hline 1878 & Eva & Guano Schooner detained; "insult to flag” \\
\hline 1879 & & $\begin{array}{l}\text { Grace Line ships Chile/Peru; confiscation and } \\
\text { neutrality }\end{array}$ \\
\hline 1879 & Lamar & Peru; misuse of US flag as convenient \\
\hline 1880 & Forest Belle & South Seas; insurance arson \\
\hline 1880 & Merritt and Newcomb & \\
\hline & George Washington & at least four ships \\
\hline & Hattie Haskell & off Cuba; boarded and detained \\
\hline 1880 & Isabel, Isluga & War of the Pacific; neutrality in Chile \\
\hline 1881 & Diana & Japan, fired on schooner, "outrage" \\
\hline
\end{tabular}

Sources: Kenneth Hagan, American Gunboat Diplomacy and the Old Navy, 18771889,Contributions in Military Studies (Westport, CN: Greenwood, 1972). Hagan covers both the Grace Line ships in 1879 p. 132, and the Forest Belle incident in 1880, p. 113. Lamar: FRUS, 1879; Rising Sun: NYT, 12 July 1877; Eva: NYT, 8 January 1878; ships off Cuba, 1880: NYT, 20 July and 5 August 1880; Isabel, Isluga: NYT, 5 November 1880; Diana: NYT, 26 December 1881.

The War of the Pacific, as well as the other encounters of U.S. merchant ships with foreign authorities over the fifteen years following the Civil War, fed into the arguments of those who sought to bolster and rebuild the U.S. Navy. A congressional report of 1881 advocated the building of new ships that would take advantage of the new technologies of steam and steel. Meanwhile, naval officers and their civilian advocates were able to build institutions, such as the Naval Institute, that represented sources of information and publicity for the New Navy movement. Alfred Thayer Mahan's, publication in 1890 of The Influence of Sea Power on History was only the bestremembered of many publications urging, directly or indirectly, a strengthened navy. That

11 See Herbert Millington, American Diplomacy and the War of the Pacific (New York: Columbia University Press, 1948). 
work, and speeches and writings of other navalists, asserted that a strong nation needed a strong navy to protect its international commerce. In that context, insults and affronts to the maritime flag abroad represented excellent evidence for the need for a larger naval budget. Compounded with the obvious inferiority of the U.S. Navy even to that of Chile, the arguments carried weight, and the "White Squadron" was launched over the years $1884-1889 .{ }^{12}$

During the brief administration of James Garfield (March -September 1881), James G. Blaine served as secretary of state; Garfield's successor, Chester Arthur, replaced Blaine with Frederick Freylinghuysen, who served from 19 December 1881 until 1885. Both Blaine and Freylinghuysen were far more assertive of U.S. interests abroad than Fish had been, at least as those interests were represented by international trade, shipping, and commercial influence. During the period, the plans of the French to build a transIsthmian canal through Panama captured the imagination and interest of the U.S. public. ${ }^{13}$ Other possible routes, through

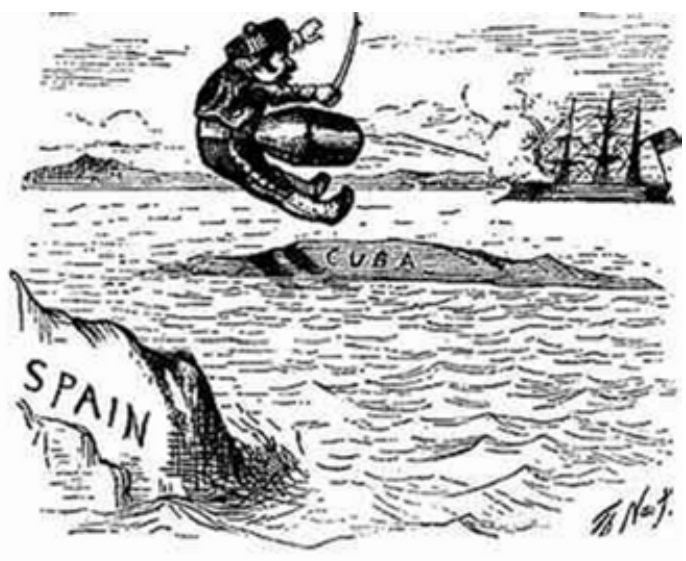

IF HE CAN'T RESPECT OUR FLAG, SEND HIM WHERE HE BELONGS

Illustration 2: Cartoon associated with the Allianca. one of several locations in Panama (then a province of Colombia), or across Nicaragua or across the Isthmus of Tehuantepec in Mexico seemed possible. U.S. interests in "Isthmian affairs," including claims, holdings, and events in and near the ports of both Nicaragua and Panama, intensified. The interest of the United States in the region was already established in the ownership of a rail line across the isthmus, operating through the period. ${ }^{14}$

Thus when insurrection movements in Panama sought independence from Colombia, it was almost inevitable that U.S.-owned and U.S.-flagged ships would become involved in the conflict. Ships seized or impounded in that conflict in 1885 are noted in Table 5.

12 For the influences on Mahan, see Robert Seager, Alfred Thayer Mahan: The Man and His Letters (Annapolis, MD: Naval Institute Press, 1977). For the emerging alliance between ship-building firms and the Navy, see Benjamin Franklin Cooling, Grey Steel and Blue Water Navy: Formative Years of America's Military-industrial Complex, 1881-1917 (Hamden, Conn.: Archon Books, 1979).

13 “American Shipping and the Panama Canal," unsigned editorial, NYT, 12 August 1879.

14 For detailed background on the U.S.-Colombian relationship in the period: E. Taylor Parks, Colombia and the United States, 1765-1934 (Durham, NC: Duke University Press, 1935), and John H. Kemble, The Panama Route, 1849-1869 (Berkeley: University of California Press, 1943). 


\section{TABLE 5 U.S. Ship Incidents, 1885}

\begin{tabular}{|l|l|l|}
\hline Year & Ships & Incident \\
\hline 1885 & Colon & Panama, commandeered by insurgents \\
\hline 1885 & Gamecock & Off Panama, seized by insurgents \\
\hline 1885 & Albano & Detained, sending arms to insurgents \\
\hline 1885 & Ambrose Light & Off Panama, disputed registry, taken by U.S. Navy \\
\hline 1885 & City of Mexico & Panama, commandeered by insurgents \\
\hline
\end{tabular}

Sources: Gamecock, Albano: FRUS, 1885, 232-33; Ambrose Light, FRUS, 1885, 275; Colon, NYT, 31 March 1885; City of Mexico: NYT, 25 April 1885.

During the administrations of Grover Cleveland (1885-1889 and 1893-1897) and Benjamin Harrison (1889-1893), the efforts of U.S. settlers, planters, and merchants in Samoa, Hawaii, Cuba, and Central America to strengthen their position often resulted in affronts to the flag, many of which occurred on merchant ships. Through the decade of the $1880 \mathrm{~s}$, such minor episodes on the high seas around the world received an increasingly bellicose reaction in the U.S. press and in official circles.

As "jingoism" became more pronounced, and Americans began to entertain the idea of international holdings in the form of coaling stations, naval bases, annexed territories, and even colonies, "insults to the flag" served as excellent means to link such aspirations to traditional nationalism. Two powerful secretaries of the navy, Cleveland's William Whitney (1885-1889) and Harrison's Benjamin Tracy (1889-1893) continued the work of transition to steam power and steel hulls; their recognition of the need for coaling stations if the steam navy was to be effective fed into the changing attitude regarding overseas expansion. $^{15}$

Rival claims to influence in the islands of Samoa nearly led to a naval war with Germany in 1889, winning further political support for naval expenditures. Meanwhile, fishing cases in Canadian, Russian, and Portuguese waters, together with continuing cases in Latin America led to at least ten more maritime "affronts to the flag."

\begin{tabular}{|l|l|l|}
\hline \multicolumn{3}{|l|}{ TABLE 6 - U.S. Ship Incidents, 1886-1891 } \\
\hline Year & Ships & Incident \\
\hline 1886 & Adams & Canada; fish and bait case \\
\hline 1886 & Marion Grimes & Canada; fishing issue \\
\hline 1887 & Merida & Nicaragua \\
\hline 1887 & William S. Moore & Nicaragua-forcible search \\
\hline 1888 & Haytian Republic & Haiti; confiscation \\
\hline
\end{tabular}

15 Richard E. Welch, Jr., The Presidencies of Grover Cleveland (Lawrence: The University Press of Kansas, 1988). 


\begin{tabular}{|l|l|l|}
\hline 1888 & Mary Frazer & Portugal, fishing episode \\
\hline 1889 & Julian and Willie & Colombia; both vessels seized \\
\hline 1891 & James H. Lewis & Russia; seizure over fishing \\
\hline
\end{tabular}

Sources: Adams: NYT, 21 May 1886; Marion Grimes: NYT, 25 December 1886; Merida: FRUS, 1887; William S. Moore: FRUS, 1887; Haytian Republic: FRUS, 1888; Mary Frazer: NYT, 7 February 1889; Julian and Willie: NYT, 24 December 1889; James H. Lewis: NYT, 29 December 1891. There were dozens of other minor encounters between New England fishing vessels and Canadian authorities, some incurring "outrage" in the New England press.

As the "New Navy" flexed its muscle with world cruises and courtesy visits to foreign ports, the ships and their crews did not always receive a friendly welcome. Two episodes, one in Chile, and another in Brazil, demonstrated that, while Americans could be angered at affronts to the maritime flag carried by merchant ships, when a U.S. Navy ship carrying the flag encountered hostility, elements of the press and public were ready to think of armed retaliation or a full-blown war. When U.S. naval officers stood up to foreign authorities, the press admired them for being "plucky.", Other "affronts," "outrages," and "insults" in the Western Hemisphere continued to demonstrate, at least to the jingo press, the need for a more effective Navy.

\begin{tabular}{|l|l|l|}
\hline \multicolumn{2}{|l|}{ TABLE 7- U.S. Ship Incidents, 1891-1895 } \\
\hline Year & Ships & Incident \\
\hline 1891 & USS Baltimore & Valparaiso, Chile (sailors killed ashore) \\
\hline 1894 & Henry Crosby & Dominican Republic \\
\hline 1894 & USS Detroit & Brazil; fired on \\
\hline 1894 & Loring Haskell & $\begin{array}{l}\text { Canada; fired on } \\
\text { Cuba; fired on by Spanish naval ship }\end{array}$ \\
\hline 1895 & Allianca & C
\end{tabular}

Sources: USS Baltimore: extensive historical literature on the incident; Henry Crosby: FRUS, 1894; USS Detroit: NYT, 15 March 1894; Loring Haskell: NYT, 10 June 1894; Allianca: NYT, 13 March 1895 and many other NYT items, March 1895.

The episode involving the Allianca nearly led to a U.S. war against Spain in 1895. Secretary of State William Whitney called the Allianca affair "a willful insult.",17 An unsigned editorial in the New York Observer and Chronicle stated that the firing on the Allianca "must be regarded as a gratuitous insult to the American flag." 18 Resentment of Spain's authority over Cuba and Cuban waters could bring the nation to the verge of war, and of course, the destruction of the USS Maine in 1898 in Havana harbor did in fact

16 "A Plucky American Admiral-How the American Flag was Protected in Rio Harbor," NYT, 14 March 1894.

17 "It was a Willful Insult," NYT, 19 March 1895, quoting from Whitney, Cleveland's secretary of state.

18 "The Allianca Incident," The New York Observer and Chronicle, 21 March 1895. 
precipitate the Spanish American War in 1898.

The diplomatic correspondence in FRUS, the articles in the New York Times and other newspapers, and scattered archival sources all suggest several patterns in the response to the episodes listed in these tables. Although there was some variation, as noted, in the reactions of the secretaries of state over the thirty-year period, all were under pressure from the press and sections of the public to provide diplomatic support to ship owners and crews in foreign waters. Such support was generally demanded even when it seemed possible or even certain that the U.S.-flagged ship was technically or

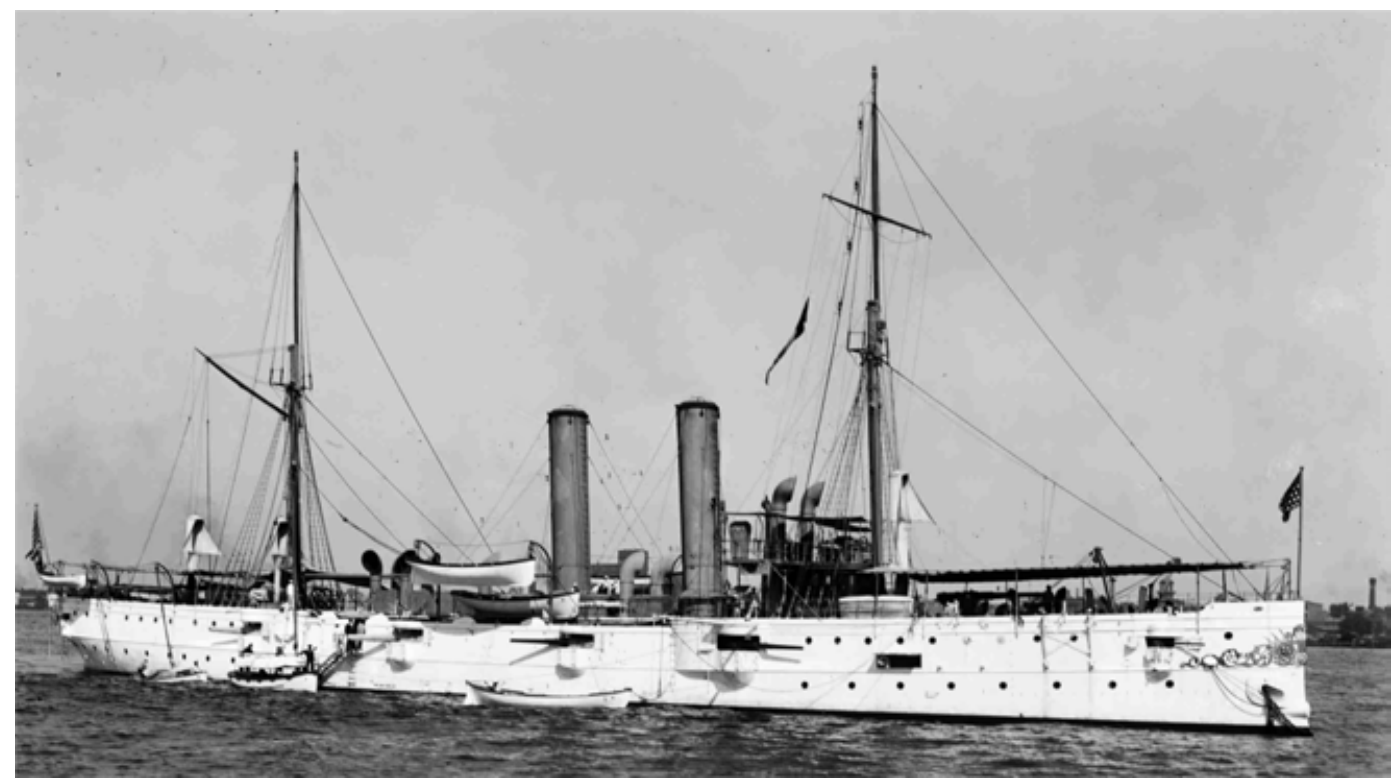

Illustration 3: USS Detroit, circa 1893-1898. Source Photo \& Graphics Co..

even clearly in violation of local or international law. U.S. jingoism was by no means unique in the period, as the so-called "Great Powers" (Britain, France, Italy, Germany and Russia) asserted their sovereignty over far-flung empires, sent warships to the Pacific, and practiced gunboat diplomacy in China and Latin America. Indeed, the very concept and term "jingo" were imported from Britain in 1878. ${ }^{19}$

With an average of more than two newsworthy episodes a year over the thirty

19 "Jingoism" meaning bellicose nationalism, and "jingo" referring to an advocate of such a nationalism were terms imported from Britain. In an 1878 music-hall song, the song-writer George Hunt composed a ditty regarding the Russo-British crisis of the period:

We don't want to fight but by jingo if we do...

We've got the ships, we've got the men, and got the money too!

The British Daily News picked up the term in March 1878, and later in the year the term entered common parlance in both Britain and the United States. The etymology of the term is explored in a website by Michael Quinon: http://www.worldwidewords.org/weirdwords/ ww-jin1.htm 
years, the plight of unprotected U.S. merchant mariners overseas was constantly before the public. The attacks were common knowledge, or "background noise" of the era. Most of the events faded from public memory after a few years and received little coverage in later historical treatments of the period. Even so, the fact that one or more such "insults" or "affronts" happened almost every year would again remind the U.S. public of the nation's low international standing. Keeping this in mind helps to place the agitation for a stronger Navy and the rise of a defensive, belligerent, and sometimes bellicose national attitude in a richer context.

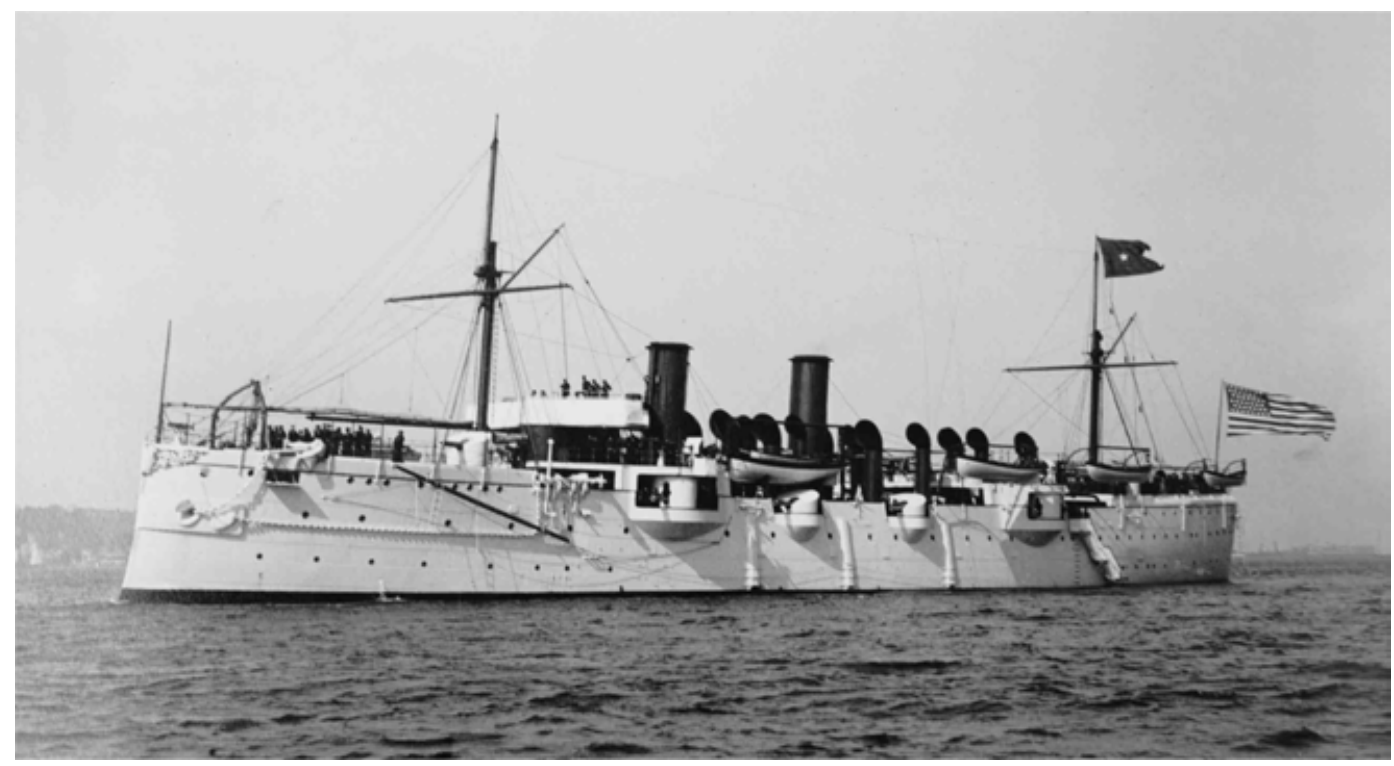

Illustration 4: USS Baltimore. Source: public domain.

Returning to the questions raised at the opening of this article, answers are offered below, but in the knowledge that they are preliminary and may well be modified by further research.

Did the treatment of U.S. merchant ships, fishing boats, and whalers in the period represent an actual or only a perceived widespread international disdain for the claim of the United States of America to being a major world power? In some of the cases, the "disdain" was demonstrated; certainly, local forces in Korea, Formosa, Central and South America would have been far more respectful if the United States had a strong naval presence in their regions.

Were the incidents exploited and blown out of proportion by commercial interest and navalist advocates in attempts to win political support? The sensitivity and the response of the press in most cases suggests a commercial and political interest in exaggerating the nature of otherwise minor episodes. But the emotion evoked by the flag's symbolism appeared genuine.

How did particular diplomats and secretaries of state deal with the issues that arose in regard to the episodes? Although generalization is difficult, it appears that the 
sensitivity to the issues varied more with the personality and administrative style of particular leaders than it did with any underlying alignment of the political parties in the period.

Was the sensitivity to "affronts" justified in any objective sense, or was it only symptomatic of the undercurrent of jingoism in the era, or as sociologists would say, the emergence of the "cult of the flag" and the conversion of the flag into a totem? The language used, both in the press and in official documents, suggests that historians will find a rich source for the rise of jingoism in these episodes, and that sociologists will see plenty of evidence for the rise of the cult of the flag.

The fact that diplomats and journalists treated the episodes as insults or affronts to the flag appeared to reflect the maritime inferiority complex, so prominently demonstrated in books and articles in the period. This extreme sensitivity to the treatment of the U.S. maritime flag abroad endured for another two decades after the Spanish American War.

That sensitivity would be central to the causes for American entry into World War I, when the German unleashing of unrestricted submarine warfare led to the loss of nine U.S. merchant ships, and the declaration of war by the United States against Germany. As demonstrated in a volume by the present author, Wilson's reluctance to involve the United States in the Great War was finally overcome by the concern of the public, the press, and his own Cabinet for the affronts to the flag suffered by U.S. merchant ships in February and March 1917. ${ }^{20}$

20 Rodney Carlisle, "The Attacks on U.S. Shipping that Precipitated American Entry into World War I," Northern Mariner/Le marin du nord, 17, no. 3 (July 2007), 41-46; and Sovereignty at Sea: U.S. Merchant Shipping and American Entry into World War I (Gainesville: University Press of Florida, 2010). 